\title{
Inhalt des XVI. Bandes
}

Das erste Buch . . . . . . . . . . . . . 11

Das zweite Buch . . . . . . . . . . . . . . . 104

Das dritte Buch . . . . . . . . . . . . . . . 219

Das vierde Buch . . . . . . . . . . . . . 318

Das fünfte Buch . . . . . . . . . . . . . . . 427

Blat-weiser. . . . . . . . . . . . . . . . 508

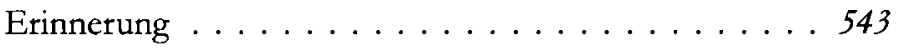

Appendix oder Zugabe . . . . . . . . . . . . . . 549

Nacbwort des Herausgebers . . . . . . . . . . . . . 579

Übersetzungen und Zitatnacbweise. . . . . . . . . . . 597 
